\title{
DIALOGUE IN AN ORGANIZATIONAL CHANGING PROCESS: CALLING FOR A SIMPLER AND DISSENSUS-DRIVEN APPROACH TO INCREASE INNOVATION
}

\author{
EL DIÁLOGO EN UN PROCESO DE CAMBIO ORGANIZACIONAL: UN GIRO HACIA UN \\ CONCEPTO MÁS SIMPLE, CON ENFOQUE CENTRADO EN EL DISENSO, PARA \\ POTENCIAR LA INNOVACIÓN
}

\begin{abstract}
Maider Gorostidi García ${ }^{1}$, mgorostidi@sinnergiak.org
Arantxa Rodríguez Berrio², arodrig@ deusto.es
\end{abstract}

Sinnergiak Social Innovation (UPV/EHU) ${ }^{1}$

Universidad de Deusto ${ }^{2}$

\begin{abstract}
In this article we analyse the existing studies on the concept of dialogue and then reflect upon the impact that this way of conceptualizing dialogue in the literature on changing processes has had on the processes themselves. From a critical perspective, we appeal to reconsider, on the one hand, the value of dialogue in change processes in complex organisational contexts. On the other hand, we call for a rethinking of the way in which dialogue is understood and, finally, we encourage a change from the approach of dialogue as a process centred on consensus and aimed-oriented. Complex contexts require new formulas to manage the diversity that enriches them.
\end{abstract}

Keywords: Dialogue, dissensus approach, organizational change, innovation.

Resumen: En este artículo hacemos un análisis sobre los estudios existentes en torno al concepto de diálogo para, después, reflexionar sobre el impacto que esta manera de conceptualizar el diálogo en la literatura sobre procesos de cambio ha tenido sobre los propios procesos en sí. Desde una perspectiva crítica, apelamos a reconsiderar, por un lado, el valor del diálogo en los procesos de cambio en contextos organizacionales complejos. Por otro lado, a reconsiderar la propia manera de entender el diálogo, y finalmente, a superar la orientación del diálogo como proceso centrado en el consenso y orientado a un logro, a un posible resultado también de consenso. Los contextos complejos requieren de nuevas fórmulas para gestionar la diversidad que los enriquece.

Palabras clave: Diálogo, enfoque de disenso, cambio organizacional, innovación.

\section{Introduction}

VUCA $^{1}$ times force organizations to adopt changes in order to adapt them to the new circumstances, so change calls for change and social complexity is brought inside the organization system. Under these complex, uncertain, volatile and ambiguous conditions new organizational paradigms are required (Romero, López, \& Bravo, 2018) to deal with this sum of challenges. And we need to hear many voices to get a better knowledge of what's coming up
(Linell, 2009), taking into account that uncertainty will remain firm becoming the new normal.

Therefore organizations get trapped in the complex world and so they are the people inside them. New rules and new meanings, perspectives and perceptions, arising from them, affect an entire system. The context and frame, thus, determine social encounters which are produce, reproduce and organized trough social relations creating cognitive structures (Linell, 2018), different ones, in every single person.

\begin{tabular}{lcl}
\hline EUROPEAN \\
PUBLI \& SOCIAL \\
INNOVATION \\
REVIEW
\end{tabular}$\quad \begin{gathered}\text { European Public \& Social Innovation Review } \\
\text { Volume 4, Issue 1, 2019 ISSN 2529-9824 } \\
\text { Creative Commons 4.0. International }\end{gathered}$


In that context, managers aim to create causal schemes and maps that give meaning to the behaviours that take place within the company helping the understanding of external environment. But the reality of the organization is not objective; it is constructed through the interaction between people and there, in this process, the symbolic power of language plays a fundamental role (Martínez-Tur, Ramón, \& Moliner, 2015).

An organizational change is, thus, a complex process (embedded in a complex world) and, as Trivedi and Misra also establish, under certain conditions, dialogue can become the glue in that change (Trivedi \& Misra, 2018). Organizational changing processes, as any other changing process, is related to the creation of reconstructed meanings and meanings are constructed and modified through human interaction (Grill, Ahlborg, \& Lindgren, 2011). So dialogue becomes a key element for organizational transformation because those processes are ruled by new ways of facing challenges (Schein, 1993).

In this article we are not going to get deep into the conditions for the dialogue to be unfold, but into the concept of dialogue itself and how the mainstream meaning (of dialogue) influences the group dialogic dynamics for changing purposes. So the aim of the article is to review how the concept of dialogue has developed and to what extent this understanding can be brought into line with an organizational changing process. We will therefore review the main research carried out on the term dialogue, its contributions to the understanding of the concept itself, what characterises a process of change in an organization and to what extent we can better understand dialogue in order to improve this understanding in favour of an ideal process of organizational change.

\section{Dialogue, an overused concept}

Dialogue, according to Schein (1993), becomes a central element of the transformation of the organization. He states that learning the theory and practice of dialogue facilitates and creates new possibilities in the communication between people in transformation processes. Dialogue, according to Schein (1993), has to be accessible (meaning helpful to organizational processes). "If dialogue is to become helpful to organizational processes, it must be seen as accessible to all of us. Unfortunately, an abstract description does not help accessibility. As we all know, "the devil is in the details" (Schein, 1993, p. 43). So how is going to be accessible if we do not have a share, clear meaning of what dialogue is?

As Schein has done, many others researchers have pointed out the growing interest dialogue has arouse in the human sciences (Cissna \& Anderson, 1998). They have also emphasized how dialogue has become a short of "fashion" concept for several disciplines centred in changing processes (education, psychologist, philosophers, journalist, teachers, researchers) (Stewart \& Zediker, 2000).

Therefore, as Wierzbicka (2006) points out, the increasing use of the concept of dialogue in the twentieth century marks the importance of dialogue but also highlights the lack of uniformity in the meaning attributed to that word. One of the purposes for studying dialogue has been the need of understanding human development and changing social processes,

\begin{abstract}
"We need ways of improving our thought processes, especially in groups where the solution depends on people reaching at least a common formulation of the problem. It is for this reason that governments, communities, and organizations are focusing increasing attention on the theory and practice of dialogue. Proponents of dialogue claim that it holds promise as a way of helping groups reach higher levels of consciousness and thus be more creative and more effective" (Schein, 1993, p. 40).
\end{abstract}

But the study of dialogue has led to different and contradictory perspectives (Botero \& Obregón, 2011) and sometimes has been oversimplified as becoming a "synonym for almost all human contact" (Stewart \& Zediker, 2000). Those who propose dialogue, do so in order to walk towards new ways of formulating problems and understanding complexity.

The word dialogue is thus confused with the very term communication (Grill et al., 2011). In this sense, the concept of dialogue has been used to refer to various and diverse realities alluding to the person, to what happens within the person and to what happens between people. The same is observed in the paper named "A critical analysis of dialogue perspectives in the literature on communication for development and social change" (Botero \& Obregón, 2011).

In 1998 Cissna and Anderson noted the increasingly keen interest that dialogue was arousing in the human sciences. They understood dialogue as a "quality" of the relationship that emerged between two or more people; they also

${ }^{1}$ VUCA is the acronym used to describe the complex reality we are living in. The notion of VUCA was created by the U.S. Army War College to describe the volatility, uncertainty, complexity and ambiguity of the world that emerged after the end of the Cold War. It is referred to as the "new normal". 
related it to the "attitude" with which participants approach each other, the way they speak and act, and the consequences of their encounter and the context in which they find themselves.

As pointed out before, one of the purposes for which dialogue has been studied it has been to define, understand and support the processes of development and social change (Botero \& Obregón, 2011), but the increased use of the concept, and the different uses by and for which it has been analysed, has generated diverse and even contradictory results. So, to better understand dialogue as a catalyst for change, we must first understand what dialogue is diving into the word itself.

\section{Dialogue, what does it mean?}

Trying to define dialogue can lead us to a profuse analysis of the various disciplines and authors who have researched it. We consider that these works have already been carried out by well known authors as Gadamer, Bohm, Buber, Bakhtin, Isaacs, Freire among others; so in order to go forward with the purpose of the article, we will consider the researches carried out by Botero and Obregón (2011) and Stewart and Zediker (2000) which analyse the way in which the concept of dialogue has been identified and classified.

In both cases, the authors start from the deep study that Anderson and Cissna (1998) carry out on the hundreds of dialogue documents published in the last decades. We believe that this meta-analysis of the concept of dialogue will help us to better understand the approach and meaning attributed to dialogue in the study of organizations and their processes of change.

\subsection{Dialogue as an element of communication}

Botero and Obregón (2011) analyse dialogue in the field of communication for development and social change (DSC). The importance of their contribution lies in the deep study they have made of the literature that advances the idea of dialogue as a relevant element of communication for development and social change. The objective of the authors is therefore twofold:

- On the one hand, they aim to better understand how dialogue has been used to define, understand and support processes of social change.
- And, on the other hand, they wish to explore the theoretical and practical implications of these different approaches (Botero \& Obregón, 2011, p. 192).

As a result of the meta-analysis carried out, they come to identify three ways of approaching the use of the notion of dialogue.

\section{a) Dialogue as a model of communication}

Dialogue is understood here as a counter model to the informational model of communication in which the recipient has a mere passive role. The dialogical approach makes it possible to include the recipient in the process of transmitting information in order to turn it into a "horizontal process of co-construction of meaning" (Botero \& Obregón, 2011, p. 193). Freire, say Botero and Obregon, is one of the exponents in this way of understanding communication (and education). In this way, they say, "It introduces a more personal dimension of communication, in which there is room for love, humanity, faith and trust. This means "dialogue implies feedback and awareness among its participants" (Botero \& Obregón, 2011, p. 194).

This way of understanding dialogue as a model of communication assumes conditions of equality among its participants, in spite of its different status, thereby incorporating more people in the creation of meanings. The recipient becomes a more active role as a result of the consideration of the other, incorporating him or her in the process of collective creation of communication and, therefore, of social change.

b) Dialogue as an event of interpersonal communication and recognition of the other

According to the yet mentioned authors (Botero \& Obregón, 2011), the works of Martin Buber (1958), Mikhail Bakhtin (1981) and Paulo Freire (2006) constitute the main theoretical foundations of this way of conceiving communication and, therefore, dialogue. They underline Buber and Bakhtin's contribution, not so much to the definition of dialogue, as to its consideration as a key element of the fact of being human. Dialogue is, thus, considered in terms of "intimate communion" (Botero \& Obregón, 2011, p. 197). Here the relational and human essence of the communicative act and the attitude of equal consideration that should characterize that encounter, are highlighted. 
In the changing process, as far as one person considers the other subject of equal value, the intention to take him or her into account, and to respect, is present and activated. So change is not a model to be imposed but a process in which we need to involve the other party in order to "decide the best way to solve social problems". (Botero \& Obregón, 2011, p. 200).

\section{c) Dialogue as a process of public deliberation}

Dialogue is also presented as a process of public deliberation in which its inherently dialectical nature is underlined. Dialogue is referred to as " $a$ conversation between two persons or groups with different ideologies, interests or worldviews"; this way of understanding it brings us closer to dialogue "as a means to solve problems, negotiate, make decisions and reflect on a given problem" (Botero \& Obregón, 2011, p. 197). Within this approach, dialogue gains instrumental value in trying to deal with divergence by moving towards convergence.

\subsection{Descriptive and prescriptive approaches to dialogue}

As mentioned before, there are two main researches done in the field of dialogue. In one hand, we have Botero and Obregón's metaanalysis; on the other, Stewart and Zediker (2000). These last two, in their attempt to make dialogue practical, make a distinction between authors who have developed the concept from what they call a descriptive approach, as opposed to those who have done so from a prescriptive approach.

The latter will, according to them, be the one that makes it possible for dialogue to be explained and learned because they put dialogue in a commodified place, making it an object (and objective) to be reached as long as it is deployed in a certain way.

What is interesting about this metaclassification is that it helps us to better situate the analysis that the theoreticians of dialogue in organizations have made of this concept. It can also allow us to see the shortcomings that this analysis may have in the contexts of organizational change.

\section{a) The descriptive approach}

The interactive, relational essence is characteristic of human nature for those authors who defend the descriptive approach of dialogue (as opposed to prescriptive). This approach alludes to the relational essence of human nature by referring to the "the irreducibly social, relational, or interactional character of all human meaning-making" (Stewart \& Zediker, 2000 , p. 225). According to these authors, one of the precursors of this descriptive way of understanding dialogue is Bakhtin, for whom dialogue responded to that relational, interactional feature. For Bakhtin, "just as the body is formed initially in the mother's womb (body), a person's consciousness awakens wrapped in another's consciousness" (Cited in Stewart \& Zediker, 2000, p. 225).

This descriptive approach shows dialogue as the essence of the person, an indissoluble ingredient to the human condition (Echeverria, 2003) understood as something that characterizes the person, referred to both, the internal dialogue that each one of us possesses, but also to the deployment that we make out there, living the casual encounters that spontaneously happen between us and the others (Shotter, 1998).

In this sense, if dialogue is that omnipresent and consequent characteristic of the human condition that, as Stewart and Zediker (2000) say, needs to be recognized and integrated, and therefore, any process of change that involves the person will have in dialogue an essential element to build the new emerging reality.

This approach seems to leave dialogue in a mere passive place in the process of change. How could we turn it into an active element of change? How can we make dialogue a generator of change in people and, by extension, in organizations? It seems that the answer to these questions lies in the consideration of dialogue from what Stewar and Zediker (2000) call a prescriptive approach.

\section{b) The prescriptive approach}

The prescriptive approach considers dialogue as that "ideal" to which human interaction can walk towards. The theories of organizational and social change that come to us from the Masachusets Institute of Technology (MIT) by Otto Scharmer (2015), William Isaacs (1999) or Linda Ellinor and Glenda Gerard (1998) go into that direction. But before going any further we should dive into a deeper analysis of what dialogue means according to the abovementioned perspective.

For the prescriptive approach, dialogue works "as an ideal to be striven toward or a goal to be achieved as an outcome of considered and ethically freighted choices" (Stewart \& Zediker, 2000, p. 227). Two main authors stand out under 
this consideration of dialogue: Buber (1937) and Bohm (1997). In words of those authors (2000, p. 227).

"The primary philosophical and pragmatic goal of Buber's use of the term "dialogue" was not just to have people recognize the inherently relational nature of all human being-although he certainly believed that all human being was relational. His goal was to understand dialogue as a special and particular quality of relation, an identifiable option."

Buber's perspective integrates the descriptive approach when it recognizes the other and recognizes that, as long as we are relational, we construct ourselves in interaction with. But in addition, in that encounter a series of characteristics must be given so that it can be qualified as dialogue.

On the other hand, Bohm drives another pragmatic oriented way of understanding dialogue when he proposes that the reality is fragmented and dialogue becomes a sort of construction of a common practice that allows this fragmentation to be overcome. (Bohm \& Nichol, 1997).

According to Stewart and Zediker (2000), this prescriptive approach has been the prevailing one in organizational psychology. It is at $\mathrm{MIT}^{2}$ that Schein (1993), Isaacs (1999), and others (Ellinor \& Gerard, 1998), cited in the first paragraph, have developed the concept and its applicability to organizations and their transformation processes.

\subsection{Simplifying dialogue conceptualization}

This prescriptive conception of dialogue is also remarked when Schein (1993) appeals to the accessible nature for the word dialogue. This accessibility has been developed into "something to achieve", a goal, an aim to reach. With this way of considering it as an achievable process or product a danger can emerges: "the parties desire unity more than truth" (Wierzbicka, 2006, p. 691). The desire to do the process in common, overcoming differences and walking together towards an ideal goal (the commonality of the construction), could frustrate any human reaction, where the inter communion from intimacy, openness, could under-considered diversity or even divergent opinions (Wierzbicka, 2006).
Gomila (2016) points this idea staying that such a big amount of literature related to dialogue, and coming from different disciplines, could lead us to danger and confusing processes where possible achievable results could be more important than the process itself. So perhaps what we are dealing with now is with the need of making dialogue a simpler concept that allows us to explore its broader potential of dialogue in innovation or organizational changing processes. By doing so, we could get the overall purpose of opening up for more voices understanding that tensions or different interest are not something to overcome "but a possible vehicle of change" (Kristiansen, 2013, p. 104).

In that case, we will follow Wierzbicka's work in his article "The concept of 'dialogue' in cross- linguistic and cross-cultural perspective", due to its simplicity. For her, dialogue "implies that each party makes a step in the direction of the other, not that they reach a shared position or mutual warm feeling. It does not imply full mutual understanding - the closeness which no longer requires words." (Wierzbicka, 2006, p. 692). It is, thus, the mere intention of taking the other into consideration accepting that he or she is part of the process to be built.

\section{The importance of difference, or diversity, in the emergence of the new}

A changing process is "a land where we are caught between what was and what might be" (O'Hara, 2003). Consequently it is a place where the new is yet to be built but the construction is determined by the old (of the past) and the desired (of the future). It is a space in which the present moment has to be reread by creating new meanings. According to Stacey, the present has to be reread "in the Hegelian dialectic" way, by opposites negating each other. It is in this tension where new meanings emerge (Stacey, 2003) and are created in a circular way: "Here meaning is emerging in the action of the living present in which the immediate future (response) acts back on the past (gesture) to change its meaning" (Stacey, 2003, p. 61).

At this stage we can say that if social interaction is embedded and embodied (Linell, 2009) and "individual identities are forming and being formed by social identities" (Stacy, quoting Elias), organizational changing (and relational) processes are far away from becoming a linear I-Thou path (Buber, 1937). We, as human, perceive reality in different, fragmented 
and biased (Matute, 2008) ways (Bohm \& Nichol, 1997) and each of us may respond in different, unpredictable, ways (Stacey, 2003), unpredictable ones, to different realities embodied and embedded in us. This difference or diversity is important to be in the potential for transformation (Stacey quoting Mead, 2003).

But if we take into consideration the prescriptive and consensus-oriented conceptualization of dialogue, within the mainstream literature of management (Kristiansen \& Bloch-Poulsen, 2010), we can loss the greater of human interaction in transformative processes. "The discourse of dialogue may construct a vision (...) of dialogue as a self-evidently positive, power-free space for communication among equals (...)" (Phillips, 2011, p. 12).

This quotation shows us a scenario far away from characterizing a transformation. Under the prescriptive approach eyes natural tensions or dissents are seeing as something to avoid, that is poorly regarded or that even constitutes an obstacle to carrying out a process of change (that seeks that monological voice). So what we find is a sort of "panacea without questioning, for example, its potential to disguise covert agendas or power relations" (Heath et al., 2006, p. 342).

But if we want to bring dialogue into organizational processes, with all of its transformational potential, we cannot ignore the context, the power relations and the social patterned dynamics that underlie organizational reality (Heath et al., 2006).

\section{How to bring the multi voices of the organization in changing processes}

In an organizational change (as in every single change in live) "as the rules are turned aside but before new norms have yet to be established, we must now all deal with rapidly rising levels of uncertainty and ambiguity" (O'Hara, 2003, pp. 66-67). Once we live captured in this land of uncertainty, caught between what was and what might be" as O'Hara stated, we will be living the tension as a natural status until something new emerges or new meanings of the organizational reality are created.

But as we have pointed out before following Stacey's words (2003), meaning mergers "in the action of the living present in which the immediate future (response) acts back on the past (gesture) to change its meaning. Meaning is not simply located in the past (gesture) or the future (response) but in the circular interaction between the two in the living present."

And meaning not also lies "in the gesture alone but in the whole social act."

In other words, meaning arises in the responsive interaction between actors and gesture and response can never be separated but must be understood as moments in one act. Meaning does not arise first in each individual, to be subsequently expressed in action, nor is it transmitted from one individual to another but, rather, it arises in the interaction between him or her. Meaning is not attached to an object, formed as a representation, or stored, but is created in the interaction" (Stacy, 2003, p.61).

So the construction of a desired future, due to a changing process, is a complex one and considers two main factors: human interaction and context in which the (inter)action is performed and patterned. This complexity is very well describe by Stacey when he narrates the dynamics of conversational life:

"Conversational processes display the dynamic analogous to the 'edge of chaos,' where patterning themes have the paradoxical characteristics of continuity and spontaneity at the same time. The felt qualities of such conversations are liveliness, fluidity and energy but also a feeling of grasping at meaning and coherence. There is excitement but also, at the same time, tension and anxiety. When conversational processes are characterized by this kind of dynamic, they have the potential for transformation" (Stacey, 2003 p. 79).

By allowing these paradoxes to arose in a changing process we allow future to be created and changes to occur. "The characteristics of fluid conversation with transformative potential are thus of great importance (...) and "Transformative potential arises in conversations when participants are diverse, that is, sufficiently different to each other. In these conditions interaction may amplify small differences into major discontinuous changes in understanding. It is in their struggling to understand each other influid, spontaneous conversational exchanges that people change. However, this is by no means an easy communicative process. First, it entails misunderstanding, which is usually experienced as frustrating, even distressing, as well as stimulating and exciting. However, the pressure to relieve the frustration may well lead to the closing down of conversational exploration, making transformation a highly precarious 
process. This connection between misunderstanding and change is an important and provoking insight" (Stacey, 2003 p. 80).

So dialogue in an organizational changing process brings us an opportunity to take differences, in order to listen to multiple perspectives (Wilhelmson, 2006), by considering the other as another voice to be present. This is the place of opportunities in change processes or innovation processes in organizations, closer to the dissensus approach (Kristiansen \& BlochPoulsen, 2010) (rather than the consensus one), to deal with the "microcosmos of threat and opportunities" to get "new discoveries" (O’Hara, 2003 p. 71-72) points out.

\section{Dialogue as a dissensus based approach to drive changing processes}

The sense of dissent is not the dissent itself, the mere fact of disagreeing, but the opportunity it generates in a group or team, involved in a changing process, to listen to what allows us to do something new that generates an opportunity. It is, therefore, vital to speak up (FMLM, 2018) and address tensions and differences (Stewart \& Zediker, 2000) (Baxter \& Montgomery, 1996). If no room is dedicated to different voices to be heard, invalid routines are produce creating a big monological voice for the change.

In the dissensus approach advanced by Kristiansen and Bloch-Poulsen (2010), dialogue is seen as a product and process fighting within the consensus-dissensus tension. Even though Kristinasen's article deals with Employee Driven Innovation in Team, we consider it as a valid one from the moment in which the concept of innovation implies a change in itself that happens in the organizational context. So we'll consider Dissensus Approach a valid one for the purpose of this article and as we see innovation and organizational change as complementary processes.

Dissensus Approach combines two things:

1. Dissensus organizing: "Team conversations must be organized in ways where silent or unspoken critical voices, speak up."

2. Dissensus sensibility: "The previous demands that team members, managers, etc. develop dissensus sensibility to open up for more voices, for indirect criticism, and for more democracy in the decision process" (Kristiansen \& BlochPoulsen, 2010, p. 156)

The combination of these two characteristics of the dissensus approach plays with dialogues trying to balance them in multidimensional tensions between consensus and dissensus and between product and process. Consequently, we may find ourselves with a tension between consensus as a product and dissensus as a process, a tension between consensus as well as dissensus as a process, a tension between the systems world and the life world, (Kristiansen \& Bloch-Poulsen, 2010) creating a rich space to hold for the change.

Figure 1. Difference scenarios considering dialogue dimensions.

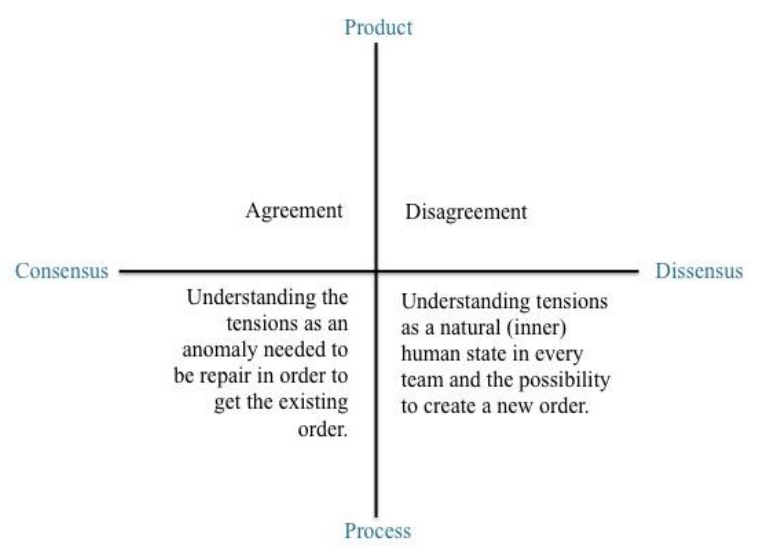

Source: Adapted from Kristiansen \& Bloch-Poulsen (2010).

Therefore, when we consider dialogue in organizational changing processes from a dissensus driven approach the following considerations can emerge:

- The importance that every voice be heard and every person recognized because there is no one excluded in the intention of reaching consensus

- The emphasis on process above product or result.

- The importance of non-rational and emotional modes of consciousness and action.

- The desire-indeed necessity- to participate in the decisions that affect one.

- The importance to the many of the one, of a common humanity expressed in a diversity of voices. 
- The willingness to acknowledge feelings.

If, according to Stacey and its Theory of Complex Responsive Processes of Relating (2003), human action and (inter) action is responsive (more than adaptive), the natural and expected behaviour to something that could be a change process is responsive.

The kind of dialogue needed in a changing process should, then, be closer to a dissensus based one. Dissensus driven dialogue is a dialogue in constant movement, as is relational, according to Stacey, and it represents a significative experience by letting people living the process. New meanings need to be created from the interaction, but other type of conversation should be generated in order to achieve potential transformations.

If we consider, as Stacey's points out, "human relating to be inherently pattern forming" (Stacey, 2003, p. 66), thus dissensus or more "dialectical" dialogues, have their place in complex context (as an organizational changing process) and they should be respected as a potential way for better transformative processes, without facing them as something to be fixed.

\section{Conclusions}

In a complex organizational context, and within the changing processes they have to face, " $(. .$. people will have partially divergent experiences, and thus knowledge, values and attitudes will be differentially distributed (...)" (Linell, 2018, p. 148). If we want those processes to be as rich as we need to be (Senge, 1998) (in order to be effective and adaptive to new emerging uncertain realities) we need dialogue to be unfold and understand in a simpler and a naturally dissensus-conceived way.

We have to overcome the reductionist way of considering dialogue as product or consensus oriented activity from a prescriptive approach, transcending its instrumental value in trying to deal with divergence by moving towards convergence.

Taking dialogue as the process that activate the conscious of taking the other into consideration could broadened our gaze towards it and managed to overcome the barriers that other ways of defining and classifying it have generated. In this way, also inspired by Linell (2009) (and his Bathkin's perspective), we also integrate the very dialogical nature of dialogue into its own conceptualization.
Simple and dissensus based concept of dialogue could let us overcome these barriers connected to organizational changing processes:

- The assumption of the equal condition among participants. In processes of organizational change, hierarchy, roles and the display of power, formal and informal, are emerging variables that cannot be ignored.

- The assumption of dialogue as a path to walk (among divergence) in order to get convergence. An organizational changing process assumes divergence and diverse as an internal feature of the polyphonic nature of the organization itself.

- The passive role of the person characterized as dialogic in the same way that he or she is characterized as human. Dialogue cannot be reduced to a mere human characteristic, to a mere relational quality. To the extent that a process of change requires the people within it to co-create new regions of meaning, to that extent dialogue becomes a working object that unfolds certain process clues materialized in that common intention to take people into account.

- The consideration of dialogue as a mere ideal to be achieved. This ideal connects with the consensus as a result. The risk here is to nullify a process with no tangible results because it could be considered as leading the group nowhere; or invaliding the process' diversity in the name of unity. In an organizational changing process we need to invite as many voices as possible and we need to consider the importance of the process itself irrespective of whether or not there is a result.

Further studies on how to unfold this dissensus based perspective should be done in these changing processes in order to tackle organizational complexity and open the global limited understanding of dialogue itself towards innovation. 


\section{References}

Baxter, L. A., \& Montgomery, B. M. (1996). Relating: Dialogues and Dialectics (1 edition). New York: The Guilford Press.

Bohm, D., \& Nichol, L. (1997). Sobre el diálogo (Edición: New; D. G. Raga \& F. M. Zahonero, Trads.). Barcelona: Editorial Kairós SA.

Botero, A. Á., \& Obregón, R. (2011). Un análisis crítico de las perspectivas de diálogo en la literatura sobre comunicación para el desarrollo y cambio social: Abordajes y desafíos. Signo y Pensamiento, 30(58), 190205.

Buber, M. (1937). I and Thou (1st Edition). Recuperado de http://archive.org/details/IAndThou_572

Cissna, K. N., \& Anderson, R. (1998). Theorizing about Dialogic Moments: The Buber-Rogers Position and Postmodern Themes. Communication Theory, 8(1), 63-104. https://doi.org/10.1111/j.14682885.1998.tb00211.x

Echeverria, R. (2003). Ontología del lenguaje (Sexta Edición). Chile: Comunicaciones Noreste Ltda.

Ellinor, L., \& Gerard, G. (1998). Dialogue: Rediscovering the trasforming power of conversation. Canada: John Wiley \& Sons, Inc.

FMLM. (2018). Speaking truth to power by Megan Reitz, Lilly Lecture 2018 [Archivo de vídeo]. Recuperado de https://vimeo.com/270639254

Gomila, A. (2016). La perspectiva de segunda persona: Mecanismos mentales de la intersubjetividad. $\begin{array}{lllll}\text { Contrastes. Revista Internacional } & \text { fe }\end{array}$ https://doi.org/10.24310/Contrastescontrastes.v0i0.1448

Grill, C., Ahlborg, G., \& Lindgren, E. C. (2011). Valuation and handling of dialogue in leadership: A grounded theory study in Swedish hospitals. Journal of Health Organization and Management, 25(1), 34-54. https://doi.org/10.1108/14777261111116815

Heath, R. L., Pearce, W. B., Shotter, J., Taylor, J. R., Kersten, A., Zorn, T., ... Deetz, S. (2006). The processes of dialogue: Participation and legitimation. Management Communication Quarterly, 19(3), 341-375.

Kristiansen, M. (2013). Dynamics between Organisational Change Processes and Facilitating Dissensus in Context Inquiring Dialogues. International Journal of Action Research; Leverkusen, 9(1), 95-123.

Kristiansen, M., \& Bloch-Poulsen, J. (2010). Employee Driven Innovation in Team (EDIT) - Innovative Potential, Dialogue, and Dissensus, 42.

Linell, P. (2009). Rethinking Language, Mind, and World Dialogically. United States of America: Information Age Publishing Inc.

Linell, P. (1990). The power of dialogue dynamics. En I. Markova \& K. Foppa, The Dynamics of dialogue (p. 238). New York: Harvester Wheatsheaf.

Martínez-Tur, V., Ramón, J., \& Moliner, C. (2015). Psicología de las organizaciones. Madrid: Síntesis.

Matute, H. (2008). Nuestra mente nos engaña. Sesgos y errores cognitivos que todos cometemos. (1 edición). Madrid: El País.

O'Hara, M. (2003). Cultivating Consciousness: Carl R. Rogers's Person-Centered Group Process as Transformative Androgogy. Journal of Transformative Education, 1(1), 64-79. https://doi.org/10.1177/0095399703251646

Phillips, L. (2011). The Promise of Dialogue: The dialogic turn in the production and communication of 
knowledge. https://doi.org/10.1075/ds.12

Romero, A. M., López, M. M., \& Bravo, A. M. (2018). La transición hacia organizaciones evolutivas Teal. Economía industrial, (407), 61-72.

Scharmer, O. (2015). Teoria U Liderar desde el futuro a medida que emerge. Barcelona: Elefthería.

Schein, E. H. (1993). On dialogue, culture, and organizational learning. Organizational Dynamics, 22(2), 40-51. https://doi.org/10.1016/0090-2616(93)90052-3

Senge, P. M. (1998). La Quinta Disciplina: Como Impulsar el Aprendizaje en la Organizacion Inteligente. Granica SA-Adelphi S.A., Ediciones.

Shotter, J. (1998). The Dialogical Nature of our Inner Lives. Philosophical Explorations, 1(3), 185-200. https://doi.org/10.1080/10001998098538699

Stacey, R. (2003). Complex Responsive Processes in Organizations: Learning and Knowledge Creation (Edición: 1). Routledge.

Stewart, J., \& Zediker, K. (2000). Dialogue as tensional, ethical practice. Southern Communication Journal, 65(2-3), 224-242. https://doi.org/10.1080/10417940009373169

Trivedi, C., \& Misra, S. (2018). Dialogue and the Creation of Transformative Social Change: The Case of Social Enterprises. Informing Science: The International Journal of an Emerging Transdiscipline, 21, 107-132. https://doi.org/10.28945/4012

Wierzbicka, A. (2006). The concept of 'dialogue' in cross-linguistic and cross-cultural perspective. Discourse Studies, 8(5), 675-703. https://doi.org/10.1177/1461445606067334

Wilhelmson, L. (2006). Dialogue Meetings as Nonformal Adult Education in a Municipal Context. Journal of Transformative Education, 4(3), 243-256. https://doi.org/10.1177/1541344606290439

William Isaacs. (1999). Dialogue and the art of thinking together: A pioneering approach to communicating in business and in life. New York: Doubleday. 